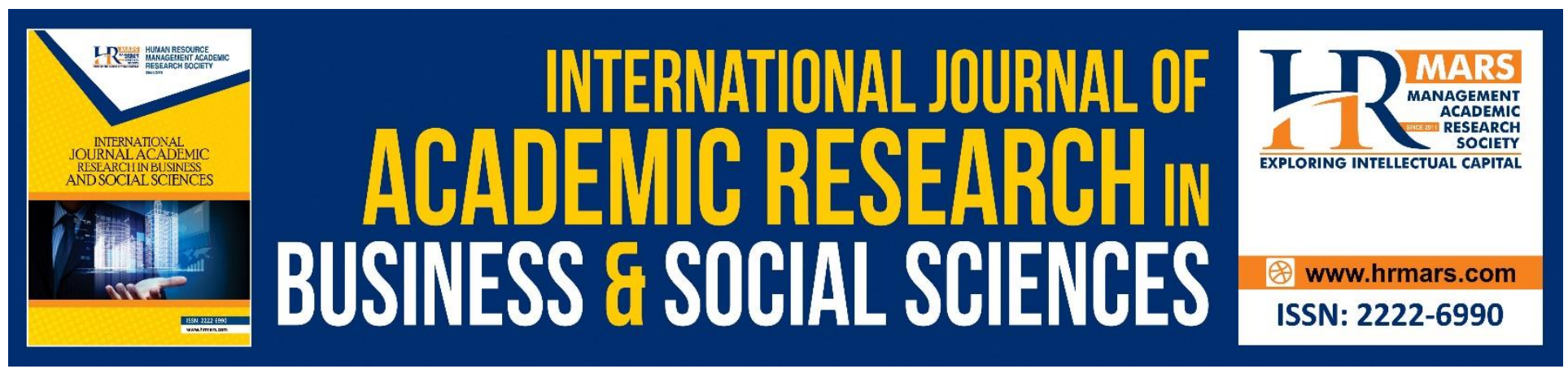

\title{
Effect of Personality Traits on Dysfunctional Audit Behaviour
}

\section{Muhammad Aamir, Siti Zaleha Abdul Rasid, Shathees Baskaran} Faiza Manzoor

To Link this Article: http://dx.doi.org/10.6007/IJARBSS/v8-i12/5190

DOI: $10.6007 /$ IJARBSS/v8-i12/5190

Received: 10 Nov 2018, Revised: 14 Dec 2018, Accepted: 21 Dec 2018

Published Online: 28 Dec 2018

In-Text Citation: (Aamir, Rasid, Baskaran, \& Manzoor, 2018)

To Cite this Article: Aamir, M., Rasid, S. Z. A., Baskaran, S., \& Manzoor, F. (2018). Effect of Personality Traits on Dysfunctional Audit Behaviour. International Journal of Academic Research in Business and Social Sciences, 8(12), 1189-1202.

\section{Copyright: (c) 2018 The Author(s)}

Published by Human Resource Management Academic Research Society (www.hrmars.com)

This article is published under the Creative Commons Attribution (CC BY 4.0) license. Anyone may reproduce, distribute, translate and create derivative works of this article (for both commercial and non-commercial purposes), subject to full attribution to the original publication and authors. The full terms of this license may be seen

at: http://creativecommons.org/licences/by/4.0/legalcode

Vol. 8, No. 12, 2018, Pg. 1189 - 1202

http://hrmars.com/index.php/pages/detail/IJARBSS

JOURNAL HOMEPAGE

Full Terms \& Conditions of access and use can be found at http://hrmars.com/index.php/pages/detail/publication-ethics 


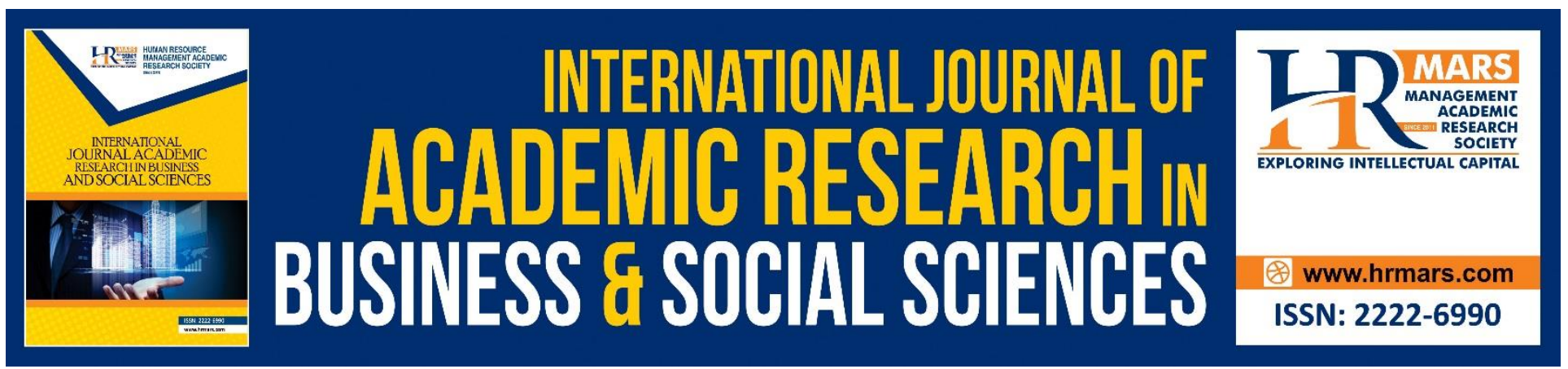

\title{
Effect of Personality Traits on Dysfunctional Audit Behaviour
}

\author{
Muhammad Aamir \\ Hailey College of Commerce, University of the Punjab, Lahore, Pakistan \\ Azman Hashim International Business School, Universiti Teknologi Malaysia, Kuala Lumpur, \\ Malaysia \\ Email: aamir@hcc.edu.pk
}

Siti Zaleha Abdul Rasid

Azman Hashim International Business School, Universiti Teknologi Malaysia, Kuala Lumpur, Malaysia

\section{Shathees Baskaran}

Azman Hashim International Business School, Universiti Teknologi Malaysia, Kuala Lumpur, Malaysia

\section{Faiza Manzoor}

Faculty of Technology Management and Business, Universiti Tun Hussein Onn Malaysia, Batu Pahat, Johor, Malaysia.

\begin{abstract}
Auditor behaviour has been under the focus of researchers for quite some time now but it has lately been more emphasized because of the recent major corporate failures. Dysfunctional audit behaviour $(D A B)$ is linked with reduced audit quality and is a widespread problem. Extant research does not adequately seem to find out the enablers and predictors of DAB. Archival research suggests that an individual's personality can predict his or her behaviour. Therefore, considering the importance of personality as the determinant of behaviour, there is a need to explore auditor's personality. It is expected that studying auditor's personality would give a better insight into the DAB problem. Empirical evidence on the relationship between personality and dysfunctional audit behaviour is still lacking. Therefore this paper attempts to examine the concept of personality, big five personality trait model for the evaluation of personality and its relationship with dysfunctional audit behaviour. It also reviews the existing literature on the relationship between personality and its different
\end{abstract}


INTERNATIONAL JOURNAL OF ACADEMIC RESEARCH IN BUSINESS AND SOCIAL SCIENCES

Vol. 8, No. 12, Dec, 2018, E-ISSN: 2222-6990 @ 2018 HRMARS

dimensions with $D A B$. Finally, it proposes a conceptual relationship between big five personality traits and DAB.

Keywords: Personality, Big Five Personality Traits, Dysfunctional Audit Behaviour

\section{Introduction}

Independent external auditors are responsible for conducting an objective and independent review of corporation's financial statements and issue an opinion as to whether they present a true and fair view of company's financial position (Smith and Emerson, 2017). Ceresney (2016) termed auditors as "critical gatekeepers" in the process of financial reporting. Thus, anything that has the capability to negatively affect the audit quality is a matter of apprehension for all stakeholders (Herrbach, 2001). Dysfunctional auditor behaviour (DAB) has been under examination and attention of researchers because it is associated with audit failure and reduced audit quality (Tervo, Smith and Pitman, 2014). Dysfunctional audit behaviour is a continuing concern and a large number of auditors are engaging in it deliberately and not out of ignorance (Nehme, Mutawa and Jizi, 2016) and it still remains challenging (Smith and Emerson, 2017). In addition, Barrainkua and Espinosa-Pike (2015) highlight that in spite of attention from watchdogs, professionals and researchers, evidence on unethical practices and behaviours about audit profession remain existent. Researchers and scholars have stressed the need to find out enablers and predictors of DAB (Herda and Martin, 2016; Broberg, Torbjorn, Argento, Gyllengahm and Martensson, 2016; Nehme, 2017).

There is an agreement among the psychologists and researchers that an individual's personality has the capacity to influence his or her behaviour and personality traits are determinants of behaviour (Robertson and Callinan, 1998). Lightner, Adams and Lightner (1982) declared that personal beliefs affect an auditors' inclination to engage in dysfunctional audit behaviour. Malone and Roberts (1996) also professed that personal characteristics of auditors are amongst the reasons of auditor's dysfunctional behaviours. Additionally, it is also established that organizations can evaluate the personality of its members to forecast their several workplace behaviours (Lee, Ashton and Vries, 2005; Marietza, 2010). Building on these findings, researchers have endeavoured to find out the effect of personality and its different components on DAB (Kelley and Margheim, 1990; Rayburn and Rayburn, 1996; Gundry, 2006; Gundry and Liyanarachchi, 2007; Donnelly, Jeffrey and O'Bryan, 2003a; Marietza, 2010; Baldacchino, Tabone, Agius and Bezzina, 2016) but what is missing in the existing literature is an integration of the combined personality approach as a determinant of DAB. Big five personality trait model is considered a comprehensive and universally accepted framework for the evaluation of an individual's personality (Digman, 1990; Barrick and Mount, 1991; Schmitt et al., 2007; Garcia, 2012; Judge, Rodell, Klinger, Simon and Crawford, 2013). Therefore, this review paper attempts to explore the relationship between personality traits and DAB and endeavours to propose a conceptual relationship between these two constructs.

\section{Research Design}

This paper is a qualitative review of the concept of personality, big five personality trait, concepts of dysfunctional audit behaviour and the relationship between personality and dysfunctional audit behaviour. For this purpose, extensive literature is reviewed from research 
INTERNATIONAL JOURNAL OF ACADEMIC RESEARCH IN BUSINESS AND SOCIAL SCIENCES Vol. 8, No. 12, Dec, 2018, E-ISSN: 2222-6990 C 2018 HRMARS

journals, books, reports, internet sources and proceeding of academic conferences. Relevant studies are summed up in the following sections and concluding remarks are stated in the last section.

\section{Personality}

Personality is one of the extensively studied constructs in the field of psychology. Personality psychology is considered a completely separate discipline of psychology (Larsen and Buss, 2008) and the personality theorists and researchers are termed as "Personologists" (Murray, 1938). The central objective of personality psychology is to build a logical image of a human being and his/her core psychological processes and to study the human nature as how they are alike to, or dissimilar from each other (Hjelle and Ziegler, 1992). The word "personality" originated from the Greek term "persona" that means "mask". In ancient Greek theatre, the masks were used to depict a character in order to conceal his/her identity (Hjelle and Ziegler, 1992).

Many researchers have defined personality in their own way according to their discipline and domain of studies but still there does not seem any agreement on the definition of the personality. Allport (1963) defined personality as "a dynamic organization, inside the person, of psychophysical systems that create the person's characteristic patterns of behaviour, thoughts and feelings" (p. 28). Winggins (1979) stated that personality is concerned with a systematic explanation of ways in which persons vary from one another. According to Pervin, Cervone and John (2005), personality is the features of an individual that explain consistent patterns of thinking, feelings and behaviour. Hartmann (2011) claimed that personality denotes the stable characteristics that articulate the concept of self in a person and leads to behaviour. Recently, Schultz and Schultz (2016) described personality as "the unique, relatively enduring internal and external aspects of a person's character that influence behaviour in different situations" (p. 9). In light of these definitions, it can be concluded that personality is a blend of an individual's intrinsic and extrinsic traits that guide his behaviour.

For classifying individual's personalities, scholars and personologists have presented different models and theories (Abdullah, Omar and Panatik, 2016) but the generally accepted and comparatively a balanced approach is known as trait approach of personality. In trait theories, theorists and psychologists are mainly concerned with the measurement of personality traits. Personality traits are the lasting characteristics that define an individual's behaviour (Robbins, Judge and Sanghi, 2009). Pervin and John (2001) described personality traits as the characteristics of the person that account for consistent feeling, thinking and behaving. Similarly, Kassin (2003) defined traits as habitual patterns of behaviour, thoughts and emotions. It can be concluded that personality traits are the stable traits of human's personality. For last few decades, a general accord has been observed among the researchers on the big five personality model that consists of five universally accepted traits of personality including openness to experience, conscientiousness, extraversion, agreeableness and neuroticism (John and Srivastava, 1999; McCrae and Costa, 2003; Gosling, Rentfrow and Swann, 2003; (Cobb-Clark and Schurer, 2012). These big five personality traits are discussed here. 
Openness to Experience: Openness to experience personality trait refers to the individual's tendency to experience new ideas, and products or services (Maltby, Day and Macaskill, 2007). It distinguishes imaginative, innovative and inventive people from the shy and conservative ones (Larsen and Buss, 2005). Individuals who score high in openness to experience are creative, sensitive, open-minded, novel, social and have a good aesthetic sense (Rothmann and Coetzer, 2003). Individuals who score low on openness to experience are generally the traditionalist, passive and are resistant to change (Costa and McCrae, 1992; Rothmann and Coetzer, 2003).

Conscientiousness: The second of five big personality traits is conscientiousness. Initially, scholars called it dependability or conformity (Fiske, 1949; Hogan, 1986). Conscientiousness is defined as "will to achieve" (Digman and Takemoto-Chock, 1981). Conscientiousness is referred to as the extent of systematic organization, determination, control and enthusiasm in focused behaviour (Maltby et al., 2007). Conscientious individuals attain success through planning and determination (Costa and McCrae, 1992). This trait is related to positive professional results and is normally anticipated by employers (Funder, 2001). Among all personality traits, it is considered to be the best judge of job performance and is linked with professional accomplishments across different professions (Barrick and Mount, 1991; Ozer and Benet-Martinez, 2006).

Extraversion: Extraversion refers to the degree of an individual's sociability. It is also known as surgency (Smith, 1967; Norman, 1967; Digman, 1990). In Eysenck's theory, extraversion is featured as engagement with the outside world, having a nature to be gregarious, welcoming, and impulsive and venturesome (Maltby et al., 2007). They are passionate and like to assert themselves and are attention seekers (Ashton, Lee and Paunonen, 2002). Barrick and Mount (1991) stated that extravert individuals are talkative, social, action-oriented, outgoing, inspired and vigorous. On the contrary, introverts lack the energy, liveliness and activity level as demonstrated by extraverts (Larsen and Kasimatis, 1990).

Agreeableness: Agreeableness is the most anticipated personality trait that mirrors individual differences in concern with social harmony in today's dynamic world (Graziano and Tobin, 2002). Agreeableness is also labelled as likeability, friendliness and social conformity by some academics (Fiske, 1949; Guilford, 1990; Goldberg, 1981). Agreeable individuals are considered cooperative and they also look for cooperation in return (Rothmann and Coetzer, 2003). They see an optimistic and bright side of life and they assume others as honest, decent and trustworthy (Costa and McCrae, 1992a). Agreeableness is found to have a negative association with success in some job roles (Barrick and Mount, 1991).

Neuroticism: Neuroticism, also termed as emotional stability denotes the tendency of feeling negative emotions (Larsen and Buss, 2005). Neuroticism refers to "variances of individual tendency to experience suffering and is defined as emotionally insecure and uneven" (Costa and McCrae, 1992, p.14). Neurotic individuals observe feelings like annoyance, fretfulness, depression, low self-control. These individuals get angry easily, are thoughtless, and they often manage ineffectively ( $O^{\prime} B$ rien, 
INTERNATIONAL JOURNAL OF ACADEMIC RESEARCH IN BUSINESS AND SOCIAL SCIENCES Vol. 8, No. 12, Dec, 2018, E-ISSN: 2222-6990 @ 2018 HRMARS

Terry and Jimmieson, 2008). Less neurotic individuals are secure, tranquil, organized and are free from persistent destructive emotions (Costa and McCrae, 1992a; Rothmann and Coetzer, 2003).

\section{Dysfunctional Audit Behaviour}

For better comprehension of dysfunctional audit behaviour, it is important to understand the term dysfunctional behaviour. Any behaviour that can harm the wellbeing of an organization and is harmful to members of the organization is considered as dysfunctional behaviour (Fleet and Griffin, 2006). Applebaum, Laconi and Matousek (2007) stated that such behaviours arise generally in the workplace where numerous behaviours with different consequences to an organization and its members occur. Dysfunctional behaviour is contained within in the taxonomy of antisocial behaviour. Giacalone and Greenberg (1997) described the antisocial behaviour as "any behaviour that brings harm or is intended to bring harm, to an organization, its employees, or stakeholders" (p. vii). Peterson (2002) termed dysfunctional behaviour as an employee's bad conduct that adversely affects work quality and work relations and has high costs both monetarily and socially for the organization. There are similar negative behaviours like dysfunctional behaviour are found in the literature including counterproductive work behaviours, workplace deviance, workplace incivility etc.

Argyris first used dysfunctional behaviour term in accounting context in 1952 (Paino, Ismail and Smith, 2010). Jaworski and Young (1992) defined dysfunctional behaviour as "to violate system rules and procedures" (p. 18). Hartmann (2000) asserted that dysfunctional behaviour is not simply "irrational" behaviour rather these are reactions that can be sensibly expected in response to control and processes. The extent, to which these controls are expected to affect the performance assessments and eventually rewards, are also seen as having an effect on managerial stresses and tension, therefore, leading to likely dysfunctional behaviour (Hartmann, 2000).

Certain actions of auditors that cause substandard audits are called dysfunctional audit behaviours (Donnelly et al., 2003a). Dysfunctional audit behaviour is also labelled as reduced audit quality behaviour (RAQB) and quality threatening behaviour (QTB) (Otley and Pierce, 1996; Coram, $\mathrm{Ng}$ and Woodliff, 2003; Bedard, Deis, Curtis and Jenkins, 2008). Reduced audit quality acts are the actions undertaken the auditor during the conduct of audit which incongruously deteriorate the effectiveness of the evidence collecting processes (Kelley and Margheim, 1990; Malone and Roberts, 1996). Herrbach (2001) described reduced audit quality acts as "poor execution of an audit procedure that reduces the level of evidence gathered for the audit so that the collected evidence is unreliable, false, or inadequate quantitatively or qualitatively" (p. 790). DAB may include totally overlooking the principles and regulations of the audit or might be guiltless errors of auditors who are not aware the requirements related to their job or beyond their capability and competence (Donnelly, Quirrin and Bryan, 2002). These behaviours include failing to research a technical issue, accepting weak client explanations, superficial review of documents, rejecting unusual items from the sample, false sign off of audit procedures and under-reporting of time spent on the audit are examples of auditor's action that can lead to lower the audit quality. 
INTERNATIONAL JOURNAL OF ACADEMIC RESEARCH IN BUSINESS AND SOCIAL SCIENCES

Vol. 8, No. 12, Dec, 2018, E-ISSN: 2222-6990 @ 2018 HRMARS

\section{The relationship between Personality and Dysfunctional Audit Behaviour}

Different people react differently to ethical issues. Dysfunctional audit behaviour gives rise to ethical problems; for a better understanding of the manifestations of the DAB, auditor's personality becomes an interesting subject to be studied (Gundry and Liyanarachchi, 2007). Therefore, researchers have shown their interest in examining auditor's personality with reference to DAB. Kelley and Margheim (1990) explored the direct and moderating effect of personality types on the occurrence of DABs. Gundry (2006) discovered the significant relationship between auditor's personality type and their acceptance of DAB in their study conducted in New Zealand. Similarly, Gundry and Liyanarachchi (2007) also reported a significant relationship between auditors' personality types and two types of dysfunctional audit behaviours i.e. premature sign off and accepting weak client explanations. Locus of control is a widely studied personality trait in personality psychology. Self-efficacy, self-esteem, neuroticism and locus of control are four dimensions of core self-evaluation trait of personality (Judge, Locke and Durham, 1997). Many scholars studied these dimensions of core self-evaluation trait in the relationship with auditor's engagement and acceptance of DAB. Malone and Roberts (1996) examined locus of control, need for approval, hard driving and self-esteem in relation to DAB. They confirmed that need for approval and need for achievement are predictors of reduced audit quality practices. Auditors who scored high on need for approval and need for achievement tend to avoid engaging in negative behaviours in auditing context.

Donnelly et al. (2003a) developed and tested a theoretical model to identify the locus of control and other variables as precursors of dysfunctional audit behaviour. They declared that auditors with strong internal locus of control were less inclined to accept dysfunctional audit behaviour. Their results were reconfirmed by Donnelly et al. (2003b) who revealed similar results while testing another model in which locus of control was put forward with auditor's position and commitment as antecedents of auditor's acceptance of DAB. Other researchers as Marietza (2010), Baldacchino et al. (2016) and Anugerah, Anita, Sari and Zenita (2016) examined the relationship between external locus of control and $D A B$ and reported that both variables were significantly related.

These aforementioned studies tell that personality is a significant antecedent of DAB. In these studies, personality is discussed using different models of personality like personality type $A$ and type $B$ and core self-evaluation models of personality and some other personality traits. However, what is missing in the existing literature is an integration of the combined and comprehensive personality approach as a determinant of DAB. Therefore, this study proposes to examine the relationship between personality and DAB using the five-factor model of personality also known as big five personality traits. It seems that researches have ignored the big five personality model in studying dysfunctional audit behaviour. Big five personality trait model is considered a comprehensive and universally accepted framework for the evaluation of an individual's personality (Gurven, Rueden, Massenkoff, Kaplan and Vie, 2013). Big five personality traits are also a proven precursor of different types of dysfunctional behaviours including counterproductive work behaviour, workplace deviance and workplace incivility across different contexts (Salgado, 2002; Bolton, Becker and Barber, 2010; Sliter, Withrow and Jex, 2015; Kluemper, McLarty and Bing, 2015). According to Spector (2011), 
"personality has the potential to affect the counterproductive work behavior process at every step. It can affect people's perceptions and appraisal of the environment, their attributions for causes of events, their emotional responses, and their ability to inhibit aggressive and counterproductive impulses" (p. 347). This claim strengthens the proposition that personality at different stages and in multiple ways predict negative work related behaviours.

The relationship between big five personality traits and DAB can be based on Cognitiveaffective personality theory by Mischel (1999). According to cognitive-affective personality theory, the behaviour is best anticipated by a comprehensive understanding of stable personality traits, the situation and the interaction between person and situation (Mischel and Shoda, 1995). Grounded on the theoretical underpinnings of Mischel (1999), the effect of personality traits on dysfunctional behaviour is proposed in this study. Based on the personality traits discussed above, the following research questions are formulated.

RQ1: Openness to experience is negatively related to dysfunctional audit behaviour.

RQ2: Conscientiousness is negatively related to dysfunctional audit behaviour.

RQ3: Extraversion is negatively related to dysfunctional audit behaviour.

RQ4: Agreeableness is negatively related to dysfunctional audit behaviour.

RQ5: Neuroticism is positively related to dysfunctional audit behaviour.

\section{Conclusion}

The aim of this paper was to review the concept of personality and dysfunctional audit behaviour and the relationship between these two constructs. For this purpose, extensive literature is reviewed that suggests that personality and $D A B$ are related. Although researchers have endeavoured to study personality in the relationship with DAB but there is a paucity of conceptual and empirical research on the relationship between an integrated and comprehensive approach of personality and DAB. It is also evidenced from the literature that big five personality model is most agreed the least controversial framework for the evaluation of personality of an individual. Therefore, this study suggested a conceptual model for further empirical investigation. Empirical evidence on this proposed relationship is expected to be of interest to the academia, auditors, regulatory bodies and other stakeholders. It is expected to provide an insightful understanding of the input factors towards audit quality i.e. auditor personality and behaviour during the conduct of the audit. Findings of empirical investigation would also be beneficial for the audit firms for recruitment, training, retention, performance evaluation and performance of auditors based on their personality and engagement in dysfunctional audit behaviour.

\section{References}

Abdullah, I., Omar, R., \& Panatik, S. A. (2016). A Literature Review on Personality, Creativity and Innovative Behavior. International Review of Management and Marketing, 177-182.

Allport, G. W. (1961). Pattern and growth in personality. New York: Holt, Rinehart and Winston. 
INTERNATIONAL JOURNAL OF ACADEMIC RESEARCH IN BUSINESS AND SOCIAL SCIENCES

Vol. 8, No. 12, Dec, 2018, E-ISSN: 2222-6990 @ 2018 HRMARS

Anugerah, R., Anita, R., Sari, R. N., \& Zenita, R. (2016). External Locus of Control and ReducedAudit Quality Behavior; The Mediating Effect of Auditor's Performance and Organizational Commitment. Journal of Economics, Business and Management, 353-357.

Applebaum, S. H., Laconi, G., \& Matousek, A. (2007). Positive and Negative Workplace Behaviors: Causes, Impacts and Solutions. Corporate Governance: The International Journal and Business in Society, 586-598.

Ashton, M. C., Lee, K., \& Paunonen, S. V. (2002). What is central feature of Social attention versus reward sensitivity. Journal of Personality and Social Psychology, 245-252.

Baldacchino, P., Tabone, N., Agius, J., \& Bezzina, F. (2016). Organizational Culture, Personnel Characteristics and Dysfunctional Audit Behavior. The IUP Journal of Accounting Research \& Audit Practices, 34-63.

Barrainkua, I., \& Espinosa-Pike, M. (2015). New insights into underreporting of time: the audit partner context. Accounting, Auditing \& Accountability Journal, 494-514.

Barrick, M. R., \& Mount, M. K. (1991). The big five personality dimensions and job performance: a meta-analysis. Personnel Psychology, 1-26.

Bedard, J., Deis , D. R., Curtis, M. B., \& Jenkins, J. G. (2008). Risk monitoring and control in audit firms: A research synthesis. Auditing: A Journal of Practice \& Theory, 187-218.

Bolton, L. R., Becker, L. K., \& Barber, L. K. (2010). Big Five trait predictors of differential counterproductive work behavior dimensions. Personality and Individual Differences, 537541.

Broberg, P., Torbjorn, T., Argento, D., Gyllengahm, N., \& Martensson, O. (2016). Explaining the influence of time budget pressure on audit quality in Sweden. Journal of Management \& Governance, 1-20.

Ceresney, A. (2016, September 22). Speech. Retrieved from US Secturities and Exchange Commission: https://www.sec.gov/news/speech/ceresney-enforcement-focus-on-auditors-andauditing.html

Cobb-Clark, D. A., \& Schurer, S. (2012). The stability of big-five personality traits. Economics Letters, 11-15.

Coram, P., Ng, J., \& Woodliff, D. (2003). A Survey of Time Budget Pressure and Reduced Audit Quality Among Australian Auditors. Australian Accounting Review, 38-44.

Costa, P. T., \& McCrae, R. R. (1992a). Four ways five factors are basic. Personality and Individual Differences, 653-665.

Coyne, I., Seigne, E., \& Randall, P. (2000). Predicting workplace victim status from personality. European journal of work and organizational psychology, 335-349.

Digman, J. (1990). Personality Structure: Emergence of the Five-Factor Model. Annual Review of Psychology, 417-440.

Donnelly, D. P., Quirin, J. J., \& Bryan, D. O. (2003a). Auditor Acceptance of Dysfunctional Audit Behavior: An Explanatory Model Using Auditors' Personal Characteristics. Behavioral Research in Accounting, 87-110.

Donnelly, D., Quirin, J., \& O' Bryan, D. (2003b). Attitudes toward dysfunctional audit behavior: The effects of locus of control, organizational commitment, and position. The Journal of Applied Business Research, 95-108. 
INTERNATIONAL JOURNAL OF ACADEMIC RESEARCH IN BUSINESS AND SOCIAL SCIENCES

Vol. 8, No. 12, Dec, 2018, E-ISSN: 2222-6990 @ 2018 HRMARS

Donnelly, D., Quirrin, J., \& Bryan, D. (2002). The perceived occurrence and acceptance of dysfunctional audit behavior. Journal of Forensic Accounting, 245-252.

Fiske, D. W. (1949). Consistency of the Factorial Structures of Personality Ratings from Different Sources. Journal of Abnormal Social Psychology, 329-344.

Fleet, D. V., \& Griffin , R. W. (2006). Dysfunctional Organization Culture: The Role of Leadership in Motivating Dysfunctional Work Behaviors. Journal of Managerial Psychology, 698-708.

Garcia , D. (2012). The affective temperaments: Differences between adolescents in the big five model and cloninger's psychobiological model of personality. Journal of Happiness Studies, 999-1017.

Giacalone, R. A., \& Greenberg, J. (1997). Antisocial Behavior in Organizations. Thousand Oaks; CA: Sage Publications,.

Goldberg, L. (1981). Language and Individual Differences: The search for universal in Personality Lexicons. In L. Wheeler, Review of Personality and Social Psychology (pp. 141-165). Beverly Hills: Sage.

Gosling, S. D., Rentfrow, J. P., \& Swann, B. W. (2003). A very brief measure of the Big Five Personality Domains. Journal of Research in Personality, 504-528.

Graziano, W. G., \& Tobin, R. M. (2002). Agreeableness: Dimension of Personality or Social Desirability Artefact. Journal of Personality, 695.

Guilford, J. P. (1990). Guilford-Zimmerman temperament survey. Gender roles: a handbook of tests and measures, 131.

Gundry, L. C. (2006). Dysfunctional behaviour in the modern audit environment: The effect of time budget pressure and auditors' personality type on reduced audit quality practices. Dysfunctional behaviour in: Unpublished B.Com (Hons.) Thesis of University of Otago, Dunedin, New Zealand.

Gundry, L. C., \& Liyanarachchi, G. A. (2007). Time budget pressure, auditors' personality type, and the incidence of reduced audit quality practices. Pacific Accounting Review, 125-152.

Gurven, M., Rueden, C. V., Massenkoff, M., Kaplan, H., \& Vie, M. L. (2013). How Universal Is the Big Five? Testing the Five-Factor Model of Personality Variation Among Forager-Farmers in the Bolivian Amazon. Journal of Personality and Social Psychology, 354-370.

Hartmann, F. H. (2000). The appropriateness of RAPM: toward the further development of theory. Accounting, Organizations and Society, 451-482.

Hartmann, M. (2011). Personality and ethical decision: An empirical investigation of personality traits and moral philosophy. PhD Dissertation. Carbondale: Department of Business Administration in the Graduate School, Southern Illinois Universit.

Herda, D. N., \& Martin, K. A. (2016). The Effects of Auditor Experience and Professional Commitment on Acceptance of Underreporting Time:A Moderated Mediation Analysis. Current Issues in Auditing, A14-A27.

Herrbach, O. (2001). Audit quality, auditor behavior and the psychological contract. The European Accounting Review, 787-802.

Hjelle, L. A., \& Ziegler, D. J. (1992). Personality theories: Basic assumptions, research and applications. New York: Mcgraw-Hill Inc. 
INTERNATIONAL JOURNAL OF ACADEMIC RESEARCH IN BUSINESS AND SOCIAL SCIENCES

Vol. 8, No. 12, Dec, 2018, E-ISSN: 2222-6990 @ 2018 HRMARS

Jaworski, B. J., \& Young, S. M. (1992). Dysfunctional behavior and management control: An empirical study of marketing managers. Accounting, Organizations and Society, 17-35.

John, O. P., \& Srivastava, S. (1999). The Big Five Trait taxonomy: History, measurement and theoretical perspectives. In L. A. John, Handbook of Personality: Theory and Research (pp. 102138). New York: Guilford Press.

Judge , T. A., Rodell, J. B., Klinger, R. L., Simon, L. S., \& Crawford, E. R. (2013). Hierarchical representations of the five-factor model of personality in predicting job performance: Integrating three organizing frameworks with two theoretical perspectives. Journal of Applied Psychology, 875-925.

Judge, T. A., Locke, E. A., \& Durham, C. C. (1997). The dispositional causes of job satisfaction: A core evaluations approach. Research in Organizational Behavior, 151-188.

Kassin, S. (2003). Essentials of psychology. New York: Prentice Hal.

Kelley, T., \& Margheim, L. (1990). The impact of time budget pressure, personality, and leadership variables on dysfunctional auditor behavior. Auditing: A Journal of Practice \& Theory, 21-42.

Kluemper, D. H., McLarty, B. D., \& Bing, M. N. (2015). Acquaintance ratings of the Big Five personality traits: Incremental validity beyond and interactive effects with self-reports in the prediction of workplace deviance. Journal of Applied Psychology, 237-248.

Larsen, R. J., \& Buss, D. M. (2005). Personality psychology: Domains of knowledge about human nature. New York: Mcgraw Hill Inc.

Larsen, R. J., \& Kasimatis, M. (1990). Individual differences in entrainment of mood to the weekly calenda. Journal ofPersonality and Social Psychology,, 164-171.

Lee, K., Ashton, M. C., \& Vries, R. E. (2005). Predicting workplace delinquency and integrity with the HEXACO and five-factor models of personality structure. Human Performance, 179-197.

Lightner, S. M., Adams, S. J., \& Lightner, K. M. (1982). The influence of situational, ethical, and expectancy theory variables on accountants' underreporting behavior. Auditing: A Journal of Practice \& Theory, 1-12.

Malone, C. F., \& Roberts, R. W. (1996). Factors associated with the incidence of reduced audit quality behaviors. Auditing: A Journal of Practice \& Theory, 49-64.

Maltby, J., Day , L., \& Macaskill, A. (2007). Personality, Individual Differences and Intelligence. Essex, UK: Pearson Education Ltd.

Marietza, F. (2010). Analyzing the Influence of Internal and External Factors on Auditors' Dysfunctional Behavior in Accounting Public Firms at Surabaya - Indonesia. MalaysiaIndonesia International Conference on Economics, Management and Accounting 2010, (pp. 370-384). Bangi, Malaysia.

McCrae, R. R., \& Costa, P. T. (2003). Personality in adulthood: A five-factor theory perspective. New York: Guilford Press.

Mischel, W. (1999). Personality coherence and dispositions in a cognitive-affective personality system (CAPS) approach. The coherence of personality: Social-cognitive bases of consistency, variability, and organization. In D. Cervone, \& Y. Shoda, The Coherence of Personality (pp. 3760). New York: The Guilford Press. 
INTERNATIONAL JOURNAL OF ACADEMIC RESEARCH IN BUSINESS AND SOCIAL SCIENCES

Vol. 8, No. 12, Dec, 2018, E-ISSN: 2222-6990 @ 2018 HRMARS

Mischel, W., \& Shoda, Y. (1995). A cognitive-affective system theory of personality: reconceptualizing situations, dispositions, dynamics, and invariance in personality structure. Psychological Review, 246-268.

Murray, H. A. (1938). Explorations in Personality. New York: Oxford University Press.

Nehme, R. (2017). Performance evaluation of auditors: a constructive or a destructive tool of audit output. Managerial Auditing Journal, 215-231.

Nehme, R., Mutawa, A. A., \& Jizi, M. (2016). Dysfunctional behavior of auditors the collision of time budget and time deadline; Evidence from developing country. The Journal of Developing Areas, 373-388.

Norman, W. (1967). 2800 Personality traits descriptors: Normative operating characteristics for a university population. Michigan: Department of Psychology, University of Michigan.

O’Brien, T. B., Terry, D. J., \& Jimmieson, N. L. (2008). Negative affectivity and responses to work stressors: An experimental study. Anxiety, Stress and Coping: An International Journal, 55-83.

Otley, D. T., \& Pierce, J. (1996b). Auditor time budget pressure: consequences and antecedents. Accounting, Auditing \& Accountability Journal, 31-58.

Ozer, D., \& Benet-Martinez, V. (2006). Personality and the prediction of consequentialoutcomes. Annual Review of Psychology, 401-421.

Paino, H., Ismail, Z., \& Smith, M. (2010). Dysfunctional audit behaviour: An exploratory study in Malaysia. Asian Review of Accounting, 162-173.

Pervin, L. A., Cervone, D., \& John, O. P. (2005). Personality: Theory and Research. Hoboken, NJ: John Wiley \& Sons.

Peterson, D. K. (2002). Deviant Workplace Behavior and the Organization's Ethical Climate. Journal of Business and Psychology, 47-60.

Rayburn, J. M., \& Rayburn, L. G. (1996). Relationship between Machiavellianism and Type A and ethical-orientation. Journal of Business Ethics, 1209-1219.

Robbins, S. P., Judge, T. A., \& Sanghi, S. (2009). Organizational Behavior. New Delhi: Peason, Prentice Hall.

Robertson, I., \& Callinan, M. (1998). Personality and Work Behaviour. European Journal of Work and Organizational Psychology, 321-340.

Rothmann, S., \& Coetzer, E. (2003). The Big Five personality dimensions and job performance. Journal of Industrial Psychology, , 68-74.

Salgado, J. A. (2002). The Big Five Personality Dimensions and Counterproductive Behaviors. International Journal of Selection and Assesment, 117-125.

Schmitt, D. P., Alik, J., McCrae, R. R., Benet-Martine, V., Alcalay, L., \& Ault, L. (2007). The geographic distribution of Big Five personality traits: Patterns and profiles of human self description across 56 nations. Journal of Cross-Cultural Psychology, 173-212.

Schultz, D. P., \& Schultz, S. E. (2016). Theories of Personality. Belmont, CA: Wadsworth, Cengage Learning.

Sliter, M., Withrow, S., \& Jex, S. M. (2015). It happened, or you thought it happened? Examining the perception of workplace incivility based on personality characteristics. International Journal of Stress Management, 24-45. 
Smith, G. M. (1967). Usefulness of peer ratings of personality in educational research. Educational and Psychological Measurement, 967-984.

Smith, K. J., \& Emerson, D. J. (2017). An analysis of the relation between resilience and reduced audit quality within the role stress paradigm. Advances in Accounting, 1-14.

Spector, P. E. (2011). The relationship of personality to counterproductive work behavior(CWB): An integration of perspectives. Human Resource Management Review, 342-352.

Tervo, W., Smith, L. M., \& Pitman, M. (2014). Dysfunctional Auditor Behavior: The Effects of Tone at the Top and Supervisors' Relationships. In C. Jeffrey, Research on Professional Responsibility and Ethics in Accounting (Research on Professional Responsibility and Ethics in Accounting (pp. 47-77). Emerald Group Publishing Limited.

Winggins, J. S. (1979). A psychological taxonomy of trait descritive terms: The interpersonal domain. Journal of Personality and Social Psychology, 395-412. 